\title{
The Effect of Service Quality, Price, and Brand Image on Purchasing Desicions of Moslem Wedding Equipment Service
}

\author{
Badik Anna Baroroh ${ }^{1}$, J.E. Sutanto ${ }^{2}$ \\ School Of Business and Management, Universitas Ciputra, Citraland CBD Boulevard, \\ Surabaya, Indonesia - 602198, \\ bbaroroh@magister.ciputra.ac.id \\ je.sutanto@ciputra.ac.id \\ https://doi.org/10.37715/rmbe.v1i1.1948.g1550
}

\begin{abstract}
Moslem Wedding Organizer is a form that personally helps brides and families to providing the supplies and implementation of wedding events in accordance with Islamic religious rules. The population of Surabaya city is majority moslem city that still adhering to diverse traditions and cultures, this is an opportunity for krar Suci to become the choice of moslem wedding organizer for brides in Surabaya. Several factors that are considered by the brides in making decisions about choosing wedding organizer are service quality, price, and brand image, so this study aims to determine the effect of service quality, price and brand image on the decision to purchase moslem wedding equipment. This type of research is quantitative, with the population being all Muslim couples in Surabaya who married in 2019, at the age of 19, who used the services by a wedding organizer. The sampling technique used incidental sampling with a sample size of 100 respondents who were processed using multiple linear regression analysis. The results of this study indicate that there is a positive and significant effect partially and simultaneously on service quality, price, and brand image on purchasing decisions for moslem wedding equipment services. Suggestions for the company are to improve service quality, re-analyze prices according to market, and improve brand image to be better known and trusted by the public.
\end{abstract}

Keywords - Service Quality, Price, Brand Image, Purchase Desicions, Muslim Wedding Supplies Services

1. Introduction

Marriage is the basic need of every couple, the day of the wedding is the day to look forward to, and preparing for the wedding is part of that inseparable from planning a wedding. Wedding Planners is the one of an interesting industry withodds are high, because almost every partner has a desire tomarried, and the existence of a wedding organizer can make it easier for couples. Surabaya city whose population is predominantly Moslem (85.1\%), so there are many marriages which is done in Islam, it becomes an opportunity for Moslem Wedding to find customers. Data on religious adherents in Surabaya, according to statistics during 2017 - 2019 are:

Table 1. Badan Pusat Statistik, 2019

\begin{tabular}{|l|l|}
\hline \multicolumn{1}{|c|}{ Agama } & Prosentase \\
\hline Islam & $85,1 \%$ \\
\hline Kristen & $9,1 \%$ \\
\hline Katolik & $4 \%$ \\
\hline Hindu & $0,3 \%$ \\
\hline Budha & $1,43 \%$ \\
\hline Konghucu & $0,07 \%$ \\
\hline
\end{tabular}




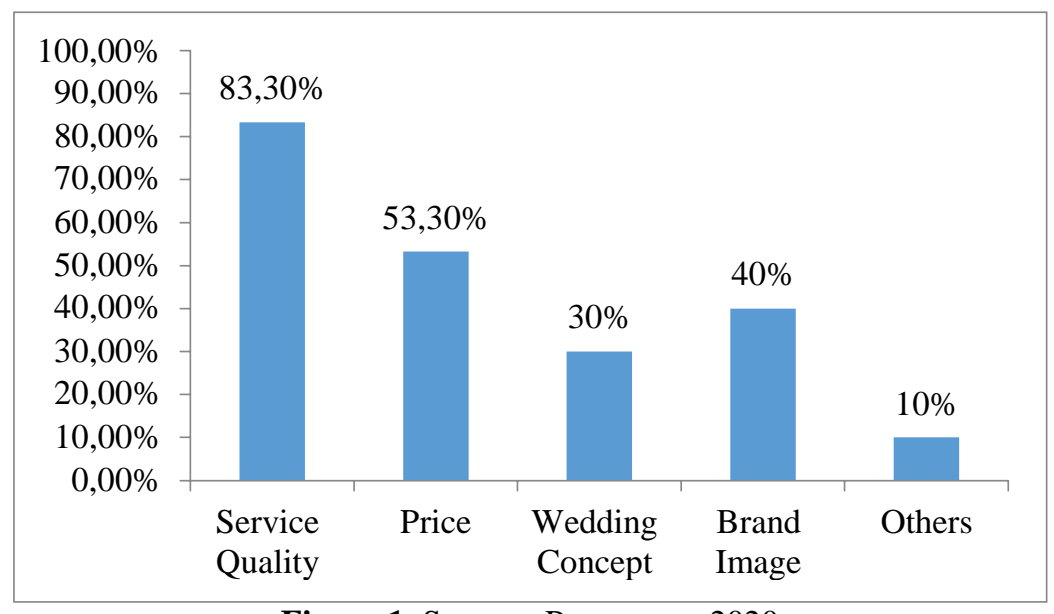

Figure 1. Source : Pra survey, 2020

Researchers conducted a pre survey of 30 Muslim couples in Surabaya who got married in 2019 with a marriage managed by Wedding Organizer related to the provision of wedding supplies, The results show that service quality (83.3\%), price (53.3\%), concept marriage (30\%), Brand Image (40\%), and others (location, recommendations brother) by $10 \%$. These five things are considered inmake the decision to choose a wedding planner.

\section{Literature Review}

\subsection{Service Quality}

Quality is an ability product / service in satisfying view based consumer needs its features and characteristics the quality of service is how high it is the level of service that the company can provide to its customers according to what the buyer has expected, which is the quality of service shows the extent to which customers can measure the benefits of the service that given by a company.

Kotler (2008), stated that there were several indicators regarding the maximum service size:

1. Tangible : seen in the form of physical facilities, equipment, personnel, and communications.

2. Empathy (emphaty) : the firm caring condition and give attention to consumers personally.

3. Reliability: the company's ability to perform services which has been promised to its consumers reliably and accurately.

4. Responsiveness (responsiveness): the willingness company to help customers in providing services in a timely manner.

5. Assurance : the trust and confidence of every employee company in form knowledge and courtesy.

\subsection{Price}

Price is included in the marketing yielding element income to generate expenses. Janah, et al (2017) stated that price to be the choice consumer before making a purchase, and the consumer will feel the benefits obtainedfrom the product used whether in accordance with the price paid. Research conducted by Novansa(2017), proves that price influence purchasing decisions. Likewise with wedding services organizer, as stated Wulanda et al (2019). Price indicators are:

1. Affordability-at-price

2. Compatibility-on-price with product-quality

3. Price-for-benefits and competitiveness-on-price

4. Discounts / Discounts

\subsection{Brand Image}

The meaning of brand image is first, the consumer's memory based assumptions about that brand reflected. second, consumers will think abstractly about brand without dealing directly with the product / service 
that is sold by company. Widyastuti et al (2017) stated that brand image can have an influence in purchasing decisions. It is in line with these things that the brand image is a reflection of what consumers experience of the brand and brand image has a positive and significant impact on purchasing decisions. Elvina et al (2019), Mufti Mubarok (2018), Sudaryanto (2019) support the statement that brand image influences buying decisions, even image strong brands not only bring in customers, but also maintain. Brand image indicators are :

1. Strength of a brand : the factors that shape the brand image as a result of the company is superior in the quality of theproduct / service it sells. The product / service has an appeal to consumers.

2. The advantages of a brand: the positive attitude that the consumer gives fulfillment wants and needs of consumers for thebenefits that given off brand.

3. Uniqueness of a brand : all the uniqueness of the product / service being sold by company.

\subsection{Purchase Decisions}

The decision purchase is the process buyer in making transactions for goods / services. While customers are often faced with the will be several companies and regarding decisions purchases that consumers decide to choose the top options several other alternatives. Dividing the dimensions of purchasing decisions into six dimensions:

1. Product selection decisions: decision making at purchase products / services. Companies certainly need to focus on each candidate consumers who have an interest-to buy a product and its alternatives might be considered buyers. For example : Need will a product, diversity of product variants / product quality.

2. The decision on the brand to choose: the brand that will be decided by the consumer for them to buy from some other brand so companies need to understand how consumers choose a brand. For example : trust in a brand and popularity of a brand.

3. Which supplier decision to choose : which supplier should be visited by consumers based on multiple considerations such as location which more close knit, low priced, over stock of goods complete and others. For example : ease of getting the desired product and product availability.

4. Quantity decisions : how many products / services to buy by consumers in the future, which allows consumers to buy morethan one

5. Decisions about when to buy : the time each consumer chooses may differ in deciding on a purchase

6. Decisions regarding the method of payment. Deep consumer decisions selection of payment methods.

There are five stages on purchase decisions that will be passed consumers, namely :

1. Recognition of needs : the first stage buyers realize that there are problems or needs that consumers need.

2. Information seeking : consumers are actively seeking information for a product / service.

3. Evaluation of alternatives : the stage where the consumer evaluates several alternative choices of brands that have been selected.

4. Purchase decision : the stage at which the consumer has decided on the brand which one is preferred.

5. Behavior on post purchase : rate based buyer actions satisfaction after making the purchase of the product / service.

In this research researchers use theory for indicators of purchasing decisions, namely product selection decisions, brand selection decisions, store selection decisions, quantity related decisions, decision time of purchase, decisions regarding method of payment.

\section{Research Method}

The conceptual framework of research This study has the aim of knowing the effect of service quality, the concept of marriage, the price on the decision to use wedding services organizer. Based on the literature review, the independent variable is obtained Service quality variable (X1), Price variable (X2), Brand image variable (X3), variable service quality, price, and brand image (X4). For the dependent variable from This research is the purchase decision $(\mathrm{Y})$. The research framework is described in the table below. 


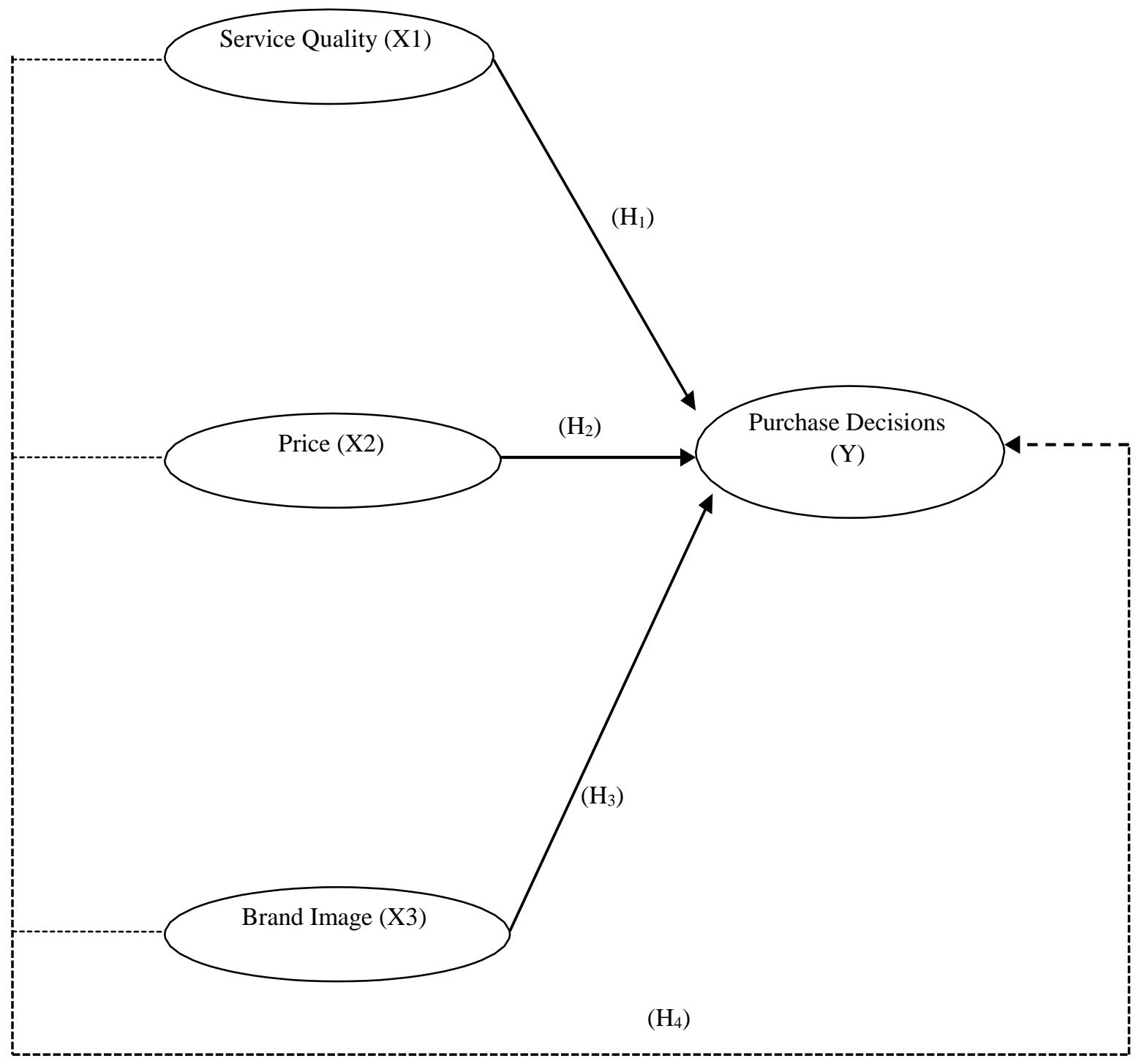

Figure 2. Empirical Research Model

\subsection{Validity and Reliability Test}

\subsubsection{Validity test}

The validity test aims to measure the validity of the questionnaire which is given to the respondent. Sugiyono (2017) said that validity is a tool that researchers use to measure a thing that should be measured. The questionnaire used will be called valid if the questions used in the questionnaire are able to show something that is already arranged by the questionnaire. This validity test using the person product moment correlation method. Is considered valid, if significance value was obtained. $<0.05$.

\subsubsection{Reliability Test}

Reliability is a series measuring instruments that are consistent even if the measuring instrument is used repeatedly. The measuring instrument used is the Cronbach Alpha, an instrument is considered reliable if it has a coefficient of 0.60 or more.

The questionnaire will be declared reliable if :

a. Value Cronbach Alpha $\geq 0.60$

b. If the value of Cronbach Alpha if Item Deleted $<$ Cronbach Alpha. 
Table 2. Result of Validity and Reliability Testing

\begin{tabular}{|c|c|c|c|c|c|c|c|}
\hline \multirow[b]{2}{*}{ Variabel } & \multirow[b]{2}{*}{ Indikator } & \multicolumn{3}{|c|}{ Uji Validitas } & \multicolumn{3}{|c|}{ Uji Reliabilitas } \\
\hline & & $\begin{array}{l}\text { Corrected } \\
\text { item-total } \\
\text { correlation }\end{array}$ & $\begin{array}{l}\text { Cronbach's } \\
\text { Alpha if } \\
\text { item } \\
\text { Deleted }\end{array}$ & Kesimpulan & $\begin{array}{c}\text { Cronbach's } \\
\text { Alpha }\end{array}$ & $\begin{array}{c}\text { Nilai } \\
\text { Kriteria }\end{array}$ & Kesimpulan \\
\hline \multirow{5}{*}{$\begin{array}{l}\text { Service } \\
\text { Quality } \\
\text { (X1) }\end{array}$} & $\mathrm{X} 1.1$ & 0,677 & 0,799 & Valid & \multirow{5}{*}{0,840} & \multirow{5}{*}{0,6} & \multirow{5}{*}{ Reliabel } \\
\hline & $\mathrm{X} 1.2$ & 0,795 & 0,761 & Valid & & & \\
\hline & $\mathrm{X} 1.3$ & 0,644 & 0,807 & Valid & & & \\
\hline & $\mathrm{X} 1.4$ & 0,565 & 0,828 & Valid & & & \\
\hline & $\mathrm{X} 1.5$ & 0,552 & 0,831 & Valid & & & \\
\hline \multirow{4}{*}{ Price $(\mathrm{X} 2)$} & $\mathrm{X} 2.1$ & 0,761 & 0,861 & Valid & \multirow{4}{*}{0,886} & \multirow{4}{*}{0,6} & \multirow{4}{*}{ Reliabel } \\
\hline & $\mathrm{X} 2.2$ & 0,788 & 0,841 & Valid & & & \\
\hline & $\mathrm{X} 2.3$ & 0,738 & 0,866 & Valid & & & \\
\hline & $\mathrm{X} 2.4$ & 0,768 & 0,849 & Valid & & & \\
\hline \multirow{3}{*}{$\begin{array}{l}\text { Brand } \\
\text { Image } \\
\text { (X3) }\end{array}$} & X3.1 & 0,785 & 0,852 & Valid & \multirow{3}{*}{0,889} & \multirow{3}{*}{0,6} & \multirow{3}{*}{ Reliabel } \\
\hline & X3.2 & 0,819 & 0,827 & Valid & & & \\
\hline & X3.3 & 0,773 & 0,851 & Valid & & & \\
\hline \multirow{6}{*}{$\begin{array}{l}\text { Purchase } \\
\text { Decisions } \\
\text { (Y) }\end{array}$} & Y.1 & 0,837 & 0,853 & Valid & \multirow{6}{*}{0,893} & \multirow{6}{*}{0,6} & \multirow{6}{*}{ Reliabel } \\
\hline & Y.2 & 0,796 & 0,860 & Valid & & & \\
\hline & Y.3 & 0,641 & 0,885 & Valid & & & \\
\hline & Y.4 & 0,610 & 0,889 & Valid & & & \\
\hline & Y.5 & 0,802 & 0,860 & Valid & & & \\
\hline & Y.6 & 0,638 & 0,888 & Valid & & & \\
\hline
\end{tabular}

Source : Output of SPSS.

\section{Results and Discussions}

Sugiyono (2017) said, multiple linear regression analysis was used if the researcher wants to estimate how the dependent variable is can go up or down (criterion), if, two, the independent variable, or, more manipulation was performed as a predictor factor. Multiple regression analysis conducted, on, research, by number, independent variables, at least 2 .

Table 3. Coefficients

\begin{tabular}{|c|c|c|c|c|c|}
\hline \multicolumn{6}{|c|}{ Purchase Decisions } \\
\hline \multirow[t]{2}{*}{ Model } & \multicolumn{2}{|c|}{ Unstandardized Coefficients } & \multirow{2}{*}{$\begin{array}{c}\begin{array}{c}\text { Standardized } \\
\text { Coefficients }\end{array} \\
\text { Beta }\end{array}$} & \multirow[t]{2}{*}{$\mathrm{t}$} & \multirow[t]{2}{*}{ Sig. } \\
\hline & B & Std. Error & & & \\
\hline (Constant) & 4.384 & 1.264 & & 3.469 & .001 \\
\hline Service Quality & .695 & .083 & .638 & 8.399 & .000 \\
\hline Price & .197 & .061 & .180 & 3.203 & .002 \\
\hline Brand Image & .296 & .126 & .172 & 2.351 & .021 \\
\hline
\end{tabular}

Based on Table, the regression equation is as follows:

$$
Y=4.384+0.695 X 1+0.197 X 2+0.296 X 3
$$

From this equation, it is interpreted:

1. The constant value (a) is 4.384. Meaningful, if the variable is quality service (X1), price (X2), and brand image (X3) value, zero or not experiencing, being, changing, means, purchasing decisions, experiencing an increase of, 4,384 . 
2. The value of the regression coefficient ( $\beta 1)$, at, the service quality variable (X1) is 0.695 . Meaning, if, the quality of service increases by one unit, then, value purchase decisions, too, increased by 0.695 units, (variable assumption free, which, another, is assumed to be constant).

3. The value of the regression coefficient ( $\beta 2$ ), variable price, (X2) 0.197. Meaningful, if the price an increase of one unit, then the value of the purchase decision increases, by 0.197 unit.

4. Regression coefficient ( $\beta 3$ ), brand image variable (X3), 0.296. Meaningful, image brand, which, increases by one unit, then the value of the purchase decision, goes up 0.296 .

\subsection{Simultaneous Significance Test (Test F)}

It is used, to perform testing as well as, to find out, influence all variables, independent together, or, simultaneously to variables bound, in a, research, also to, test for the influence, significant or even nonsignificant in the regression model. Ghozali (2018), stated the independent variable is, not included, significant explanatory for, the variable dependent. if the significance is $>0.05, H 0$ received its meaning, service quality, price, and, brand image simultaneously have, influence, significantly on purchasing decisions.

Table 4. Anova ${ }^{\mathrm{b}}$

\begin{tabular}{|l|r|r|r|r|c|}
\hline \multicolumn{1}{|c|}{ Model } & \multicolumn{1}{|c|}{$\begin{array}{c}\text { Sum of } \\
\text { Squares }\end{array}$} & \multicolumn{1}{c|}{ df } & Mean Square & F & Sig. \\
\hline Regression & 837.328 & 3 & 279.109 & 111.281 & $.000^{\mathrm{b}}$ \\
\hline Residual & 240.782 & 96 & 2.508 & & \\
\hline Total & 1078.110 & 99 & & & \\
\hline
\end{tabular}

Based on Table, it is known that the significance value of the $\mathrm{F}$ test is $<0.05$ hence service quality, price, and, brand image simultaneously have an influence significantly, to the purchase decision

\section{2. $\quad$ Significant Test for Individual Parameters (t Statistical Test)}

Statistical tests, $t$ is useful, to find out whether, on, each of the independent variables there is significant, influence against, the dependent variable. If the $t$ value $<0.05$ of significance, it means variable, independent, partially, has an influence on the dependent variable

Table 5. Model Summary ${ }^{\mathrm{b}}$

\begin{tabular}{|c|c|c|c|c|c|}
\hline \multicolumn{6}{|c|}{ Purchase Decisions } \\
\hline \multirow[t]{2}{*}{ Model } & \multicolumn{2}{|c|}{$\begin{array}{l}\text { Unstandardized } \\
\text { Coefficients }\end{array}$} & \multirow{2}{*}{$\begin{array}{c}\text { Standardized } \\
\text { Coefficients }\end{array}$} & \multirow[t]{2}{*}{$t$} & \multirow[t]{2}{*}{ Sig. } \\
\hline & $B$ & Std. Error & & & \\
\hline (Constant) & 4.384 & 1.264 & & 3.469 & .001 \\
\hline Service Quality & .695 & .083 & .638 & 8.399 & .000 \\
\hline Price & .197 & .061 & .180 & 3.203 & .002 \\
\hline Brand Image & .296 & .126 & .172 & 2.351 & .021 \\
\hline
\end{tabular}

Table 5 above shows the results of the significant test, of, parameters individual or test, $t$ obtained the significance value of the service quality variable is 0.000 which, that is, is less $(<)$ than .05 . It was concluded that, the quality variable service, influencing the purchasing decision variable, on a, partial basis, so that $\mathrm{H} 1 \mathrm{Be}$ accepted. Furthermore, the significance value of $t$ for the price variable is $0.002<0.05$.

In conclusion, the price variable partially affects the variable, the decision purchase so that $\mathrm{H} 2$ is accepted. The significance value of $\mathrm{t}$ for their image variable was $0.02<0.05$ In conclusion, the brand image variable affects the variable, the purchase decision in, partially, so that $\mathrm{H} 3$ is accepted.

\subsection{Test of the coefficient of determination (R2)}

According to Gozhali (2018), the coefficient of determination (R2) is a measurement the ability of the model in explaining variations of variables dependent. The value of the coefficient, this determination has criteria between zero or one. The value R2 approaches the number 1 the higher the information which is given 
to predict the dependent variable.

Table 6. Coeffisient of Determination Test

\begin{tabular}{|r|r|r|l|ll|}
\hline \multicolumn{5}{|c|}{ Model Summary } \\
\hline Model & $\mathrm{R}$ & R Square & $\begin{array}{l}\text { Adjusted R } \\
\text { Square }\end{array}$ & $\begin{array}{l}\text { Std. Error of the } \\
\text { Estimate }\end{array}$ \\
\hline \multicolumn{2}{|c|}{$.881^{\mathrm{a}}$} & .777 & .770 & & 1.584 \\
\hline
\end{tabular}

Based on Table it is known the value of the correlation coefficient (R) 0.881 meaningful there is a strong independent correlation between all variables to the variable dependent. Coefficient value determination (R2) 0.777 that is the ability of theindependent variables to explain the dependent variable is $77.7 \%$.

\section{Conclusion and Practical Implication}

Based on the results of the analysis and discussion of the effect of service quality, brand image, and price on purchasingdecisions for Muslim wedding equipment services it can be concluded as follows.

1. Service quality has a positive and significant effect on purchasing decisions for Muslim wedding equipment services.

2. Brand image has a positive and significant effect on purchasing decisions for Muslim wedding equipment services.

3. Price has a positive and significant effect on the decision to purchase Muslim wedding equipment services.

4. Service quality, brand image, and price together have a positive and significant effect on purchasing decisions for Muslimwedding equipment services.

\subsection{Suggestion}

From the results of the discussion that has been carried out by the author about purchasing decisions on wedding equipmentservices, the author tries to provide suggestions that are useful in doing further work:

1. For the company

With this research, it is hoped that the company will improve and improve the quality of service and communication to customers so that customers feel that they are cared for not only in the aspects of the needs of the wedding, but also from other aspects (religion, social, health, psychology), evaluate prices with local competitors whether prices are given can be accepted by customers, and improve brand image in terms of legality thereby increasing customer confidence.

2. For further researchers

In this study, researchers are not free from mistakes and shortcomings so that researchers who want to carry out the same or similar research are expected to be able to further expand the discussion regarding wedding equipment service providers with better research and develop other theories about consumer trust. such as in research journals by Febriani and Sudaryanto (2018) and about promotions on products / services by Sudaryanto et al (2019) whose names are relatedto purchasing decisions by buyers.

3. For the community

With this research, the public is able to assess what things are considered in choosing a wedding organizer so that they can compare one wedding organizer with another, not only in terms of price, but also from other factors.

\subsection{Research Limitations}

In this study offline data collection or direct interviews should be carried out but due to pandemic conditions data collection was carried out by distributing questionnaires online to all respondents thus becoming a limitation in this study.

\subsection{Acknowledgements}

In completing this thesis, the writer received a lot of help and attention from various parties. For this reason, on this occasion the author would like to thank to Mr DR. J.E. Sutanto, MM. as thesis supervisor. The author realizes that this thesis is far fromperfect, therefore constructive suggestions and criticisms are expected. Hopefully this work is useful for all of us. 


\section{References}

Devita, E. M., \& Agustini, M. Y. D. H. (2019). Country of origin and brand image on purchase decision of South Korean cosmetic etude house. Journal Of Management and Business Environment, 1(1), 55-70.

Febriani, R. R., \& Sudaryanto, B. (2018). Pengaruh brand image dan kualitas layanan terhadap kepercayaan dan keputusan pembelian pada toko online (Studi pada konsumen OLX. co. id di Kota Semarang). Diponegoro Journal Of Management, 7(2), 314-324.

Ghozali, I. (2018). Aplikasi analisis multivariete dengan program IBM SPSS 23.

Janah, M., \& Wahyuni, D. U. (2017). Pengaruh kualitas pelayanan, harga, dan promosi terhadap keputusan pembelian pada Dewi Hijab. Jurnal Ilmu Dan Riset Manajemen (JIRM), 6(4).

Kotler, P., \& Armstrong, G. (2008). Prinsip-Prinsip Pemasaran. jilid 2 Jakarta: Erlangga.

Mubarok, M. M. (2018). The effect of brand image and consumer attitudes on the decision to purchase batik jetis Sidoarjo mediated by intent to buy. Journal of Economics, Business, and Accountancy Ventura, 21(1), 105116.

Novansa, H., \& Ali, H. (2017). Purchase decision model: Analysis of brand image, rand awareness and price (Case study SMECO Indonesia SME products). Saudi Journal of Humanities and Social Sciences, 2(8), 621-632.

Sudaryanto, S., Subagio, N. A., Awaliyah, I. N., Wulandari, D., \& Hanim, A. (2019). Influence of brand image, price and promotion on consumer's buying decision of fast moving consumer's goods with culture as a moderating variable in basmallah retail store in Indonesia. International Journal of Scientific and Technology Research, 8(3), 85-92.

Sugiyono, S. (2017). Metode penelitian kuantitatif dan kualitatif dan R\&D. Bandung: Alfabeta.

Widyastuti, S., \& Said, M. (2017). Consumer consideration in purchase decision of SPECS sports shoes product through brand image, product design and price perception. International Journal of Supply Chain Management, 6(4), 199-207.

Wulanda, N., Wahab, Z., \& Widad, A. (2019). Pengaruh harga, word of mouth dan citra merek terhadap keputusan pembelian dalam memilih event organizer (Studi kasus di Un Production). Journal of Management and Business Review, 16(1), 43-70. 